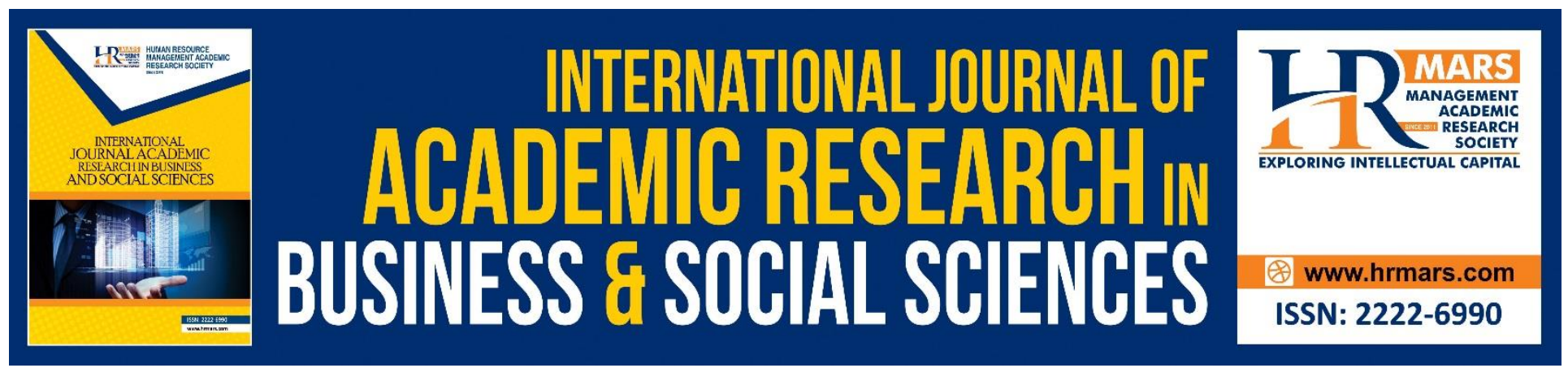

\title{
The Relationship between Internship Programs and Employability: With Special Reference to BBA Graduates of Non State University of Sri Lanka
}

\author{
K.A.N.N. Meththananda, T.G.U. Apsara, Y.M.U.J. Yapa, \\ K.U.N. Shanthirathne, Wasantha Rajapaksha, R.S. Weerarathna
}

To Link this Article: http://dx.doi.org/10.6007/IJARBSS/v8-i12/5114

DOI: $10.6007 /$ IJARBSS/v8-i12/5114

Received: 11 Nov 2018, Revised: 29 Dec 2018, Accepted: 30 Dec 2018

Published Online: 31 Dec 2018

In-Text Citation: (Meththananda et al., 2018)

To Cite this Article: Meththananda, K. A. N. N., Apsara, T. G. U., Yapa, Y. M. U. J., Shanthirathne, K. U. N., Rajapaksha, W., \& Weerarathna, R. S. (2018). The Relationship between Internship Programs and Employability: With Special Reference to BBA Graduates of Non State University of Sri Lanka. International Journal of Academic Research in Business and Social Sciences, 8(12), 955-968.

Copyright: (C) 2018 The Author(s)

Published by Human Resource Management Academic Research Society (www.hrmars.com)

This article is published under the Creative Commons Attribution (CC BY 4.0) license. Anyone may reproduce, distribute, translate and create derivative works of this article (for both commercial and non-commercial purposes), subject to full attribution to the original publication and authors. The full terms of this license may be seen

at: http://creativecommons.org/licences/by/4.0/legalcode

Vol. 8, No. 12, 2018, Pg. 955 - 968

http://hrmars.com/index.php/pages/detail/IJARBSS

JOURNAL HOMEPAGE

Full Terms \& Conditions of access and use can be found at http://hrmars.com/index.php/pages/detail/publication-ethics 


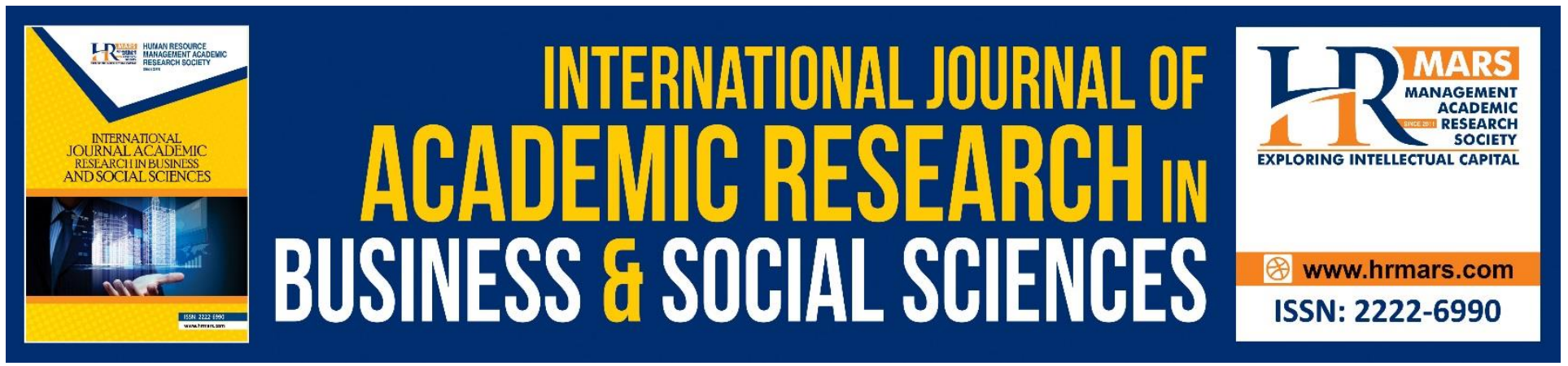

\title{
The Relationship between Internship Programs and Employability: With Special Reference to BBA Graduates of Non State University of Sri Lanka
}

\author{
K.A.N.N. Meththananda
}

Department of Business Management, Faculty of Business, Sri Lanka Institute of Information Technology, Malabe, Sri Lanka

\section{T.G.U. Apsara}

Department of Business Management, Faculty of Business, Sri Lanka Institute of Information Technology, Malabe, Sri Lanka

\section{Y.M.U.J. Yapa}

Department of Business Management, Faculty of Business, Sri Lanka Institute of Information Technology, Malabe, Sri Lanka

\section{K.U.N. Shanthirathne}

Department of Business Management, Faculty of Business, Sri Lanka Institute of Information Technology, Malabe, Sri Lanka

\section{Wasantha Rajapaksha}

Senior Lecturer, Department of Business Management, Faculty of Business, Sri Lanka Institute of Information Technology, Malabe, Sri Lanka

\section{R.S. Weerarathna}

Lecturer, Department of Business Management, Faculty of Business, Sri Lanka Institute of Information Technology, Malabe, Sri Lanka

Corresponding Author's E-mail: ranitha.w@sliit.lk

\section{Abstract}

Internship program is a strategic initiative which has been implemented by tertiary education institutes to improve the employability of graduates as the graduates' unemployment has become a 
critical issue especially in the Sri Lankan context. This study examines the relationship between internship programs and graduates' employability with the perspective of Business Management graduates who have recently passed out from the Sri Lanka Institute of Information Technology. The paper has revealed that internship programs have a strong positive relationship with graduates' employability. Further the paper reveals that technical skills which they have gained through internship programs have the strongest relationship with their employability, therefore their perception is that technical skills have the most impact towards their employability. Also the paper presents that they agree that their intention for lifelong learning has been improved by internship programs. Ultimately the study has been able to reveal that internship programs have a strong relationship with graduates' employability which is the ultimate objective of the study.

Keywords: Internship, Employability, Career Skills, Technical Skills

\section{Introduction}

Graduates' unemployment is one of the most critical issues in Sri Lanka today. According to the statistics of the survey, Department of Census and Statistics, among levels of education, highest level of unemployment rate $9.3 \%$ has been reported by the GCE A/L and above category among educational levels as shown by the table. (Central Bank Annual Report, 2016)

Table 1.1: Unemployment rate by level of education-3rd Quarter 2016

\begin{tabular}{|l|c|c|c|}
\hline \multirow{2}{*}{ Level of Education } & \multicolumn{3}{|c|}{ Unemployment Rate (\%) } \\
\cline { 2 - 4 } & Sri Lanka & Male & Female \\
\hline Sri Lanka & 4.5 & 2.7 & 7.6 \\
\hline Below GCE O/L & 2.5 & 1.9 & 3.9 \\
\hline GCE O/L & 5.8 & 4.2 & 8.8 \\
\hline GCE A/L and Above & 9.3 & 4.5 & 13.9 \\
\hline
\end{tabular}

Source: Sri Lanka Labour Force Survey 3rd Quarter-2016, Department of Census and

\section{Statistics}

Further to results of the Sri Lanka Labour Force Survey done in the third quarter of 2016, by the Department of Census and Statistics, it indicates the unemployment rate from 2011 to the $3^{\text {rd }}$ quarter of 2016. As per statistics it shows a rapid growth of the unemployment rate of the 25-29 age category which majority of the graduates pass out from universities. Also it shows an increment of unemployment rates of the category of GCE A/L/ and above. It has been shown by the Table. 
INTERNATIONAL JOURNAL OF ACADEMIC RESEARCH IN BUSINESS AND SOCIAL SCIENCES Vol. 8, No. 12, Dec, 2018, E-ISSN: 2222-6990 @ 2018 HRMARS

Table 1.2: Unemployment rate by level of education and gender-Third quarter 2016

\begin{tabular}{|c|c|c|c|c|c|c|c|c|c|c|}
\hline \multirow{2}{*}{ Indicator } & \multicolumn{10}{|c|}{ Year } \\
\hline & 2011 & 2012 & 2013 & 2014 & 2015 & $2014 Q 3$ & $2015 Q 3$ & $2016 Q 1$ & $2016 Q 2$ & $2016 Q 3$ \\
\hline \multicolumn{11}{|c|}{ Unemployment Rate } \\
\hline \multicolumn{11}{|l|}{ By gender } \\
\hline Total & 4.2 & 4.0 & 4.4 & 4.3 & 4.7 & 4.2 & 5.1 & 6.1 & 4.6 & 4.5 \\
\hline Male & 2.7 & 2.8 & 3.2 & 3.1 & 3.0 & 3.3 & 3.5 & 3.1 & 3.1 & 2.7 \\
\hline Female & 7.1 & 6.3 & 6.6 & 6.5 & 7.6 & 6.0 & 7.8 & 4.2 & 7.3 & 7.6 \\
\hline \multicolumn{11}{|c|}{ By selected age group (Year) } \\
\hline $20-29$ & 12.4 & 11.3 & 13.1 & 13.6 & 14.2 & 14.0 & 15.0 & 14.2 & 14.4 & 14.3 \\
\hline $20-24$ & 17.7 & 16.7 & 19.3 & 19.9 & 19.7 & 20.8 & 21.7 & 19.7 & 21.2 & 19.8 \\
\hline $25-29$ & 7.7 & 6.6 & 7.6 & 8.2 & 9.4 & 8.1 & 8.9 & 9.4 & 8.3 & 9.7 \\
\hline \multicolumn{11}{|c|}{ By selected education level } \\
\hline \multicolumn{11}{|c|}{ GCE A/L \& Above } \\
\hline Total & 9.1 & 7.6 & 8.7 & 8.2 & 9.2 & 8.2 & 10.3 & 7.7 & 8.6 & 9.3 \\
\hline Male & 5.4 & 4.6 & 5.7 & 5.4 & 4.7 & 6.5 & 6.1 & 5.9 & 4.6 & 4.5 \\
\hline Female & 13.2 & 10.8 & 11.8 & 11.1 & 13.5 & 9.9 & 14.3 & 9.5 & 12.5 & 13.9 \\
\hline
\end{tabular}

Source: Sri Lanka Labour Force Survey 3rd Quarter-2016, Department of Census and Statistics

As depicted in the Figure 1, records of Department of Census and statistics, the Unemployment rate among youth has reached 21.6 per cent by the fourth quarter of 2016 , compared to 21.2 per cent in the third quarter of 2016 which indicates a growth of $1.88 \%$.

Figure 1.1: Sri Lanka Youth Unemployment Rate

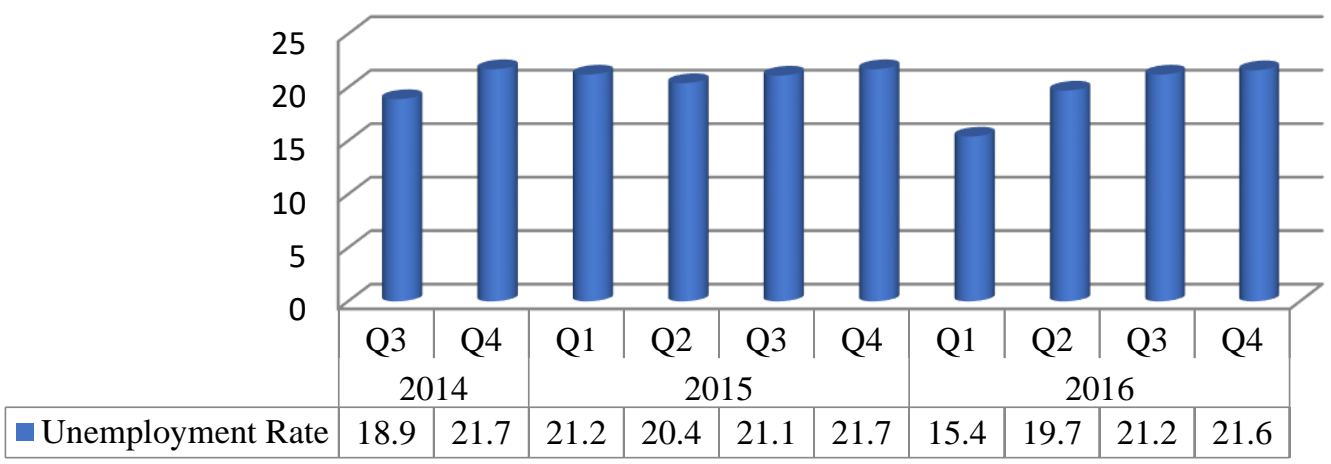

Source: TradingEconomics.Com | Department of Census and Statistics Sri Lanka

According to Department of census and statistics, no reduction or a change in the usual pattern can be seen in the youth unemployment rate. Various types of social issues have caused this issue; especially the perception of graduates to have a job in the public sector, that perception has been aggregated by election pledges given by leading political parties. 
INTERNATIONAL JOURNAL OF ACADEMIC RESEARCH IN BUSINESS AND SOCIAL SCIENCES Vol. 8, No. 12, Dec, 2018, E-ISSN: 2222-6990 C 2018 HRMARS

When it comes to survey conducted by $A B C$ University in 2016, it had recorded an unemployment rate of 35.11 percent of the total graduates of $A B C$ University as shown in the table.

Table1.3: Employability Rate of Graduates, ABC University-2016

\begin{tabular}{|c|c|c|c|c|}
\hline $\begin{array}{l}\text { Employment } \\
\text { Status }\end{array}$ & Institute & Number & Total & $\begin{array}{c}\text { Percentage } \\
(\%)\end{array}$ \\
\hline \multirow{5}{*}{ Employed } & $A B C$ University & 513 & \multirow{5}{*}{640} & \multirow{5}{*}{59.93} \\
\hline & $\begin{array}{c}\text { Partner University } 1 \\
\text { (Offered) }\end{array}$ & 81 & & \\
\hline & $\begin{array}{c}\text { Partner University } 2 \\
\text { (Offered) }\end{array}$ & 27 & & \\
\hline & $\begin{array}{c}\text { Partner University } 3 \\
\text { (Offered) }\end{array}$ & 6 & & \\
\hline & $\begin{array}{c}\text { Partner University } 4 \\
\text { (Offered) }\end{array}$ & 13 & & \\
\hline \multirow{4}{*}{ Unemployed } & Partner University 1 & 39 & \multirow{4}{*}{375} & \multirow{4}{*}{35.11} \\
\hline & $A B C$ University & 317 & & \\
\hline & Partner University 2 & 17 & & \\
\hline & Partner University 3 & 2 & & \\
\hline \multirow{6}{*}{ Not Available } & Partner University 2 & 3 & \multirow{4}{*}{53} & \multirow{4}{*}{4.96} \\
\hline & $\begin{array}{c}\text { Partner University } 1 \\
\text { (Offered) }\end{array}$ & 24 & & \\
\hline & Partner University 4 & 2 & & \\
\hline & ABC University & 22 & & \\
\hline & Partner University 3 & 2 & 1068 & \\
\hline & Grand Total & 1068 & & \\
\hline
\end{tabular}

Source: Employability Survey Records-2016, ABC University

Also when records were further analysed, it had reported an unemployment rate of $46.4 \%$ of graduates of Faculty of Business as at their graduation year. It has been shown by the table.

Table 1.4: Employability Rate of BBA Graduates, ABC University-2016

\begin{tabular}{|c|c|c|}
\hline Status & $\begin{array}{c}\text { No. of } \\
\text { Graduates }\end{array}$ & Percentage (\%) \\
\hline Employed & 66 & 52.8 \\
\hline Unemployed & 58 & 46.4 \\
\hline Not Available & 1 & 0.8 \\
\hline Total & 125 & 100 \\
\hline
\end{tabular}

Source: Employability Survey Records-2016, ABC University

Thus, graduates unemployment in Sri Lanka has been a serious social issue for nearly three decades. It is estimated that around 20,000 graduates are jobless today in Sri Lanka as cited by (Weligamage and Siengthai, 2003; Samarasinghe, 2003). Since late 1960s, graduates started 
experiencing difficulties in finding employment. Mismatch between skills possessed by graduates and skills demanded by the labour market create a gap, leading to unemployment (Devarajan, 2017). Therefore, the main reason behind this is lack of professional experience in addition to traditional theoretical education system.

Since the recent past Sri Lankan universities and higher educational institutions offer internship programs for their undergraduates to provide a transition from academic world to the work environment (Thilakarathne and Madurapperuma, 2013). Through these internship programs students are given an opportunity to get experience how theory works in the real working life and it helps students to secure their sooner employability.

On the basis of those evidences, this research aims to examine the relationship between internship programs and graduates' employability. It will also critically assess whether the internship programs make positive impact on employability in the Sri Lankan context. The researchers of this study will further examine into the issues mentioned above and the influence of those issues on the employability through internship programs. This study will give special reference to ABC University BBA Graduates those who have undergone internship programs in different organizations in Sri Lanka. The researchers will pay special attention to the facts that whether they had the opportunities to apply the theoretical knowledge gained from the tertiary education, and to what extent they applied their knowledge, how the employers/ organizations welcome their knowledge in their work processes. Researchers will further examine on how the internship program have helped them improve their competencies required for executive jobs in the market and acquire professional experience. Hence what researchers expect from this study is to explore the relationship between internship programs and graduates' employability.

\section{Research Questions}

\section{Generic Question}

What is the relationship between the internship programs and the graduates' employability?

\section{Specific Questions}

- What is the impact of internship programs towards graduates' employability?

- Which dimension of independent variable has the most impact on graduates' employability?

- What is the level of employability of BBA graduates of ABC University?

- What recommendations can be given for $A B C$ University to improve the quality of internship programs in order to increase the employability of graduates?

\section{Research Objectives}

\section{Generic Objective}

- To explore the relationship between internship programs and graduates' employability.

\section{Sub Objectives}

- To explore the impact of internship programs towards graduates' employability. 
INTERNATIONAL JOURNAL OF ACADEMIC RESEARCH IN BUSINESS AND SOCIAL SCIENCES

Vol. 8, No. 12, Dec, 2018, E-ISSN: 2222-6990 @ 2018 HRMARS

- To explore which dimension of independent variable has the most impact on graduates' employability.

- To investigate the level of employability of BBA graduates of the SLIIT.

- To make recommendations for SLIIT to improve the quality of internship programs in order to increase the employability of graduates.

\section{Literature Review}

Sri Lankan Universities and higher educational institutions offer internships for their undergraduates to provide a transition from academic world to the work environment (Thilakerathne and Madurapperuma, 2013). Through the internship programme students are given an opportunity to experience how the theory works in the real life and it help the students to secure their sooner employability. Over the decade, a large number of academic researchers have explored the positive outcomes of internships as an employability \& career development enhancer. Researchers (Clark, 2003, Hymon-Parker, 1998 \& Weible, 2010) find that advantages of internships for students are increased career opportunities, higher salaries, quicker job offers, faster promotion rates, job satisfaction, ease of transition from university to work, better communication skills, working, and applying the knowledge gained from the classroom.

As well as according to the past researches the internship process is an opportunity for organizations to develop and maintain relationship with universities while gaining exposure on university involving various characteristics of internships contributing to the student's personal and professional development. It is an opportunity for them to recruit best talented people to the organization at lower cost. Prior researches highlights various elements in internship attachments such as importance of relevant practical experience for students (Mounce, 2004), effects of internship predictors on the successful field of experience (Beardand and Morton, 1999).

Accordingly, almost all Sri Lankan families are having greater aspiration of providing university education for their children as a secured path of higher employability. Graduate unemployment in Sri Lanka has been a serious problem for nearly three decades. It is estimated that around 20,000 graduates are jobless today in Sri Lanka (Weligamage \& Siengthai, 2003). Unemployment rate among youth has reached 21.6 per cent in 2016, compared to 20.8 per cent in 2015(Central Bank Annual Report, 2016). The highest rate of unemployment on 2016 is observed in the GCE (A/L) and above category which is about $9.3 \%$. (Central Bank Annual Report, 2016). Since late 1960, graduates started experiencing difficulties in finding employment in any sector. Mismatch between skills possessed by graduates and skills demanded by the labor market creates a gap, leading to unemployment. (Devarajan, 2017).

According to the Ariyawansha (2008), unemployment is a crisis because it is not only affecting to the graduates but also it has become potent threat to the long term political stability of the nation. Especially students are facing many challenges at the end of their tenure as a student, when seeking employment (Ariyawansha, 2008). The main reason behind this is lack of professional experience in addition to traditional theoretical education system. The private sector is heavily dependent on nongraduates with certain experience or technical qualifications, especially in the areas of information 
technology (IT), marketing, and related services. When graduates possess the appropriate knowledge and skills demanded by the labour market, graduates become more employable (Dissanayake, 2011).

When considering all these things it generates a problem whether there is a relation ship between internship programs and employability or extent to which internship help for graduates to find a better job opportunity. Hence, this study is going to investigate the relationship between the internship program and graduates' employability with special reference to ABC University BBA graduates.

\section{Hypothesis and Conceptual Model}

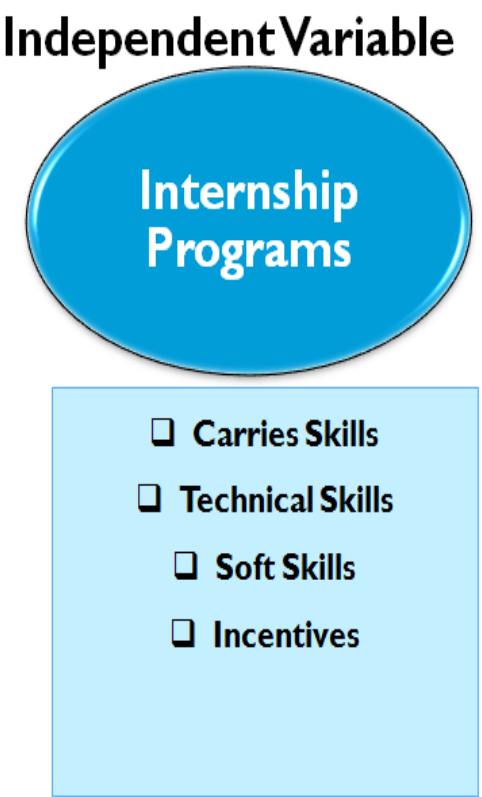

Accounting Students Evolution of Internship Experiences Togara Warinda,

Faculty of Computing, Department of Accountancy,

University of Zimbabwe, Moint Pleasnt Harare, Zimbawe

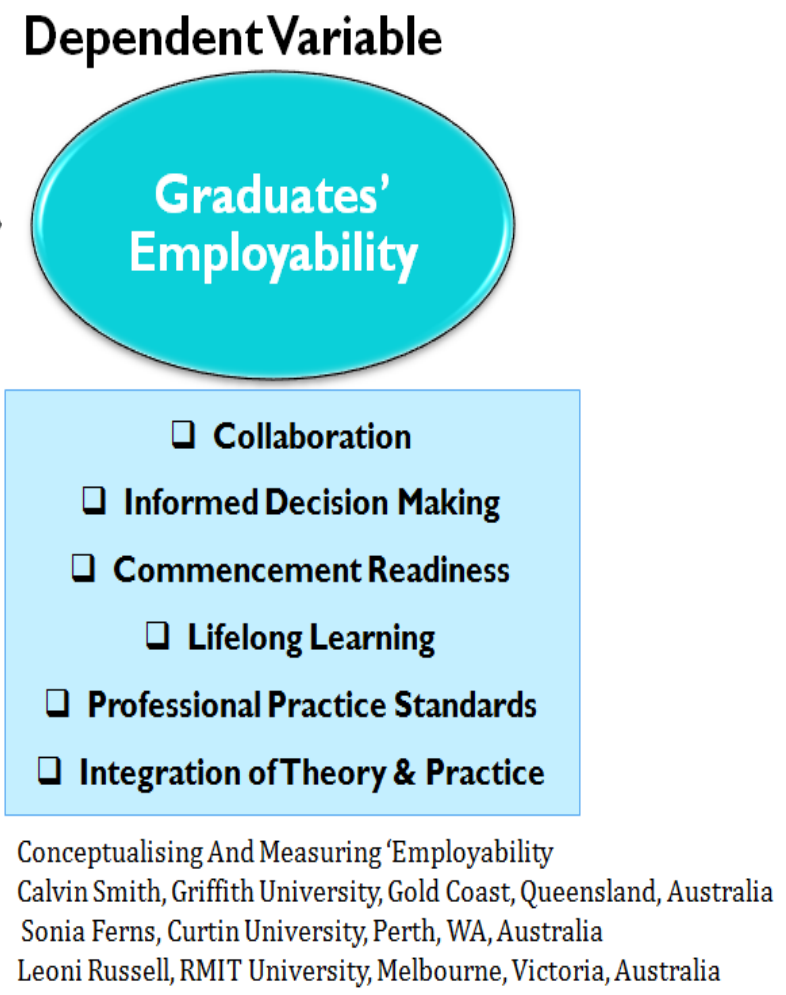

\section{Hypothesis}

- $\mathrm{H}_{0}$ There is no relationship between Internship programmes and employability $\mathrm{H}_{1}$ There is a relationship between Internship programmes and employability

- $\quad H A_{0}$ There is no relationship between career skills and employability $\mathrm{HA}_{1}$ There is a relationship between career skills and employability

- $\mathrm{HB}_{0}$ There is no relationship between technical skills and employability $\mathrm{HB}_{1}$ There is a relationship between technical skills and employability

- $\mathrm{HC}_{0}$ There is no relationship between soft skills and employability 
INTERNATIONAL JOURNAL OF ACADEMIC RESEARCH IN BUSINESS AND SOCIAL SCIENCES

Vol. 8, No. 12, Dec, 2018, E-ISSN: 2222-6990 @ 2018 HRMARS

$\mathrm{HC}_{1}$ There is a relationship between soft skills and employability

- $\mathrm{HD}_{0}$ There is no relationship between incentives and employability

$\mathrm{HD}_{1}$ There is a relationship between incentives and employability

\section{Research Methodology}

Based on the purpose of the research, this study can be classified as a cross sectional, descriptive type of research study having a quantitative process of research. And also, the research is going to investigate the relationship between internship training program and graduates' employability based on the logic in deductive nature which is important for obtaining a good grasp through subsequent theory testing. According to Sekaran (2006), descriptive study is undertaken in organizations to learn about and describe the characteristics of group members. Hence, this study is also going on the same manner, the researcher identified that this research is also a descriptive study.

This study took more than three weeks' time for data collection process from individuals who passed out as ABC University BBA graduates in 2016. Those all data which required for study were collected within a particular and continuous time period and there was no subsequent extension of the research contemplated which means data is collected once, over a short period of time before it is analysed and interpreted. After that researcher has been conducted a statistical test to find out whether there is any correlation between variables. Therefore, this study was cross-sectional in nature. In this study, researcher consider about the relationship between two variables such as internship programs and the employability with special reference to ABC University BBA graduates. Therefore, unit of analysis of this study was individuals.

Targeted population of this study is BBA graduates who passed out in 2016 at Faculty of Business, ABC University. There were 125 BBA graduates at ABC University in 2016. Then researchers selected 95 individuals as a sample size within that population by using sample calculator method. Based on that 76 BBA graduates who have an internship experience were selected as a sample again by using sample calculator method. Therefore, double sampling method is used by the researcher under this study. Researcher used both primary and secondary data to gather necessary data for the study and used a combination of two questionnaires, which were used for previous studies. The questionnaire consists of all together forty-seven (42) questions including questions on respondents' demography. This questionnaire was distributed among the selected sample. Also researchers used data from previous studies and Survey results from the ABC University.

In this study, researchers have targeted to collect data within the selected sample by distributing a developed questionnaire made by researchers. Based on the collected data of the responses hypothesis will be tested and measured association between the independent variable and the dependent variable. Apart from that researcher used secondary data for researcher's purpose and research books, journals and previous studies and survey results etc. are used as secondary data. Descriptive statistics analysis, correlation, regression analysis and one sample t-test were used to analyse the collected data. Microsoft Office Excel Package and statistical package for the social sciences (SPSS) version was used as data analysis tools. 
This study is conducted to explore the relationship between two variables such as internship programmes and graduates' employability. The study done by Warinda (2013) under the topic "Accounting Students' Evaluation of Internship Experiences from a Skills Perspective" has evaluated the Internship experiences of undergraduates with regard to career skills, soft skills, incentives and technical skills. Therefore, the independent variable which is internship programmes is divided in to four dimensions such as career skills, technical skills, soft skills, incentives according to the past relevant literature as mention in the chapter literature review to measure the independent variable. Similarly According to the article under the topic of "Conceptualizing and measuring employability" written by Smith, Ferns, and Rusell(2014), collaboration and team work, informed decision making, information literacy in context, commencement readiness, lifelong learning, professional practices and standards and integration of theory and practice were taken as dimensions for the study to measure the employability. Therefore, to measure the dependent variable which is employability it is also cascaded down in to six dimensions such as collaboration, informed decision making, commencement readiness, lifelong learning, professional practice standards and integration of theory and practice. Those dimensions were measured by using several questions. The reliability of dimensions of independent and dependent variables were tested. In the results of the reliability test all the dimension of the independent variable indicated Cronbach's alpha values above 0.7 and shows a high internal consistency level. Cronbach's alpha values of six (6) dimensions of the dependent variable were above 0.7. Accordingly, all the dimensions taken for the study was highly internal consistent and reliable.

Researchers developed a questionnaire with using a combination of two questionnaires previously used by researchers to measure same variables. To collect data, firstly, the questionnaire was distributed among a ninety-five (95) BBA Graduates who passed out from the ABC University in 2016, and through that seventy-six (76) respondents were selected on the participation to internship programs basis.

\section{Analysis and Findings}

This study has fulfilled all research objectives as specified. First sub objective of the study is to explore the impact of internship programmes towards the graduates' employability. To achieve these objective, researchers have been implemented the regression analysis for variables and dimensions of internships. The $R$ value represents the simple correlation and is 0.739 , which indicates a high degree of correlation. There by internships have a 73.5\%impact on graduates' employability.

Model Summary

\begin{tabular}{|l|r|r|r|r|}
\hline Model & $\mathrm{R}$ & \multicolumn{1}{|c|}{ R Square } & Adjusted R Square & $\begin{array}{c}\text { Std. Error of } \\
\text { the Estimate }\end{array}$ \\
\hline 1 & $.739^{\mathrm{a}}$ & .546 & .540 & 8.82716 \\
\hline
\end{tabular}

a. Predictors: (Constant), Internship

Second sub objective of the study is to explore which dimension of independent variable has the most impact on graduates' employability. To achieve this objective, researchers have been compared mean values which describes the central tendency of responses of dimensions of independent 
INTERNATIONAL JOURNAL OF ACADEMIC RESEARCH IN BUSINESS AND SOCIAL SCIENCES Vol. 8, No. 12, Dec, 2018, E-ISSN: 2222-6990 C 2018 HRMARS

variable. Accordingly mean values of three which are career skills, Technical skills and Soft skills out of all four dimensions have recorded a mean value above 4.0 which means in respondents' perspective they agree positively that all 3 skills such as soft skills, career skills and technical skills have been improved by going through an internship program. But they do not much agree on the incentive they have received during the internship which indicates 3.40 mean values.

\begin{tabular}{|l|c|}
\hline \multicolumn{1}{|c|}{ Dimension } & Mean Value \\
\hline Career Skills & 4.10 \\
\hline Technical Skills & 4.01 \\
\hline Soft Skills & 4.16 \\
\hline Incentives & 3.40 \\
\hline
\end{tabular}

Third objective of the research is to investigate the level of employability of BBA graduates of the $A B C$ University. To measure the level of employability, researchers have used one sample T-Test to determine the level of mean value. Results presented by the analysis gives a mean value of 3.93, which is a moderate value, but more towards the high level of employability, which explains that the employability level of the population is high.

\begin{tabular}{|l|c|c|c|c|}
\hline \multicolumn{5}{|c|}{ Sample Statistics } \\
\hline & $\mathrm{N}$ & Mean & $\begin{array}{c}\text { Std. } \\
\text { Deviation }\end{array}$ & $\begin{array}{c}\text { Std. Error } \\
\text { Mean }\end{array}$ \\
\hline Employability & 76 & 3.93 & 0.59 & 0.07 \\
\hline Internship & 76 & 3.92 & 0.60 & 0.07 \\
\hline
\end{tabular}

Final sub objective of this study is to make recommendations for ABC UNIVERSITY to improve quality of internship programs in order to increase the employability of graduates. Therefore, the university should be actively involved in encouraging students to go to the internship and getting organizations where they can gain the better experience on engaging in internships. It is better, if they can make participating for the internship as a compulsory requirement for the undergraduates who are following BBA degree programme because the study reveals that there is a relationship between internship programme and graduates' employability which means internship programmes are enabling for graduates to find a job because participating for the internship training programme is not a compulsory requirement of the degree programme at $A B C$ University. Also when considering dimensions used to measure the internship programmes such as career skills, technical skills, soft skills and incentives, all those three types of skills have been impacted to the employability of graduates. Similarly, the study reveals that internship programmes are enabling interns to gain those 
INTERNATIONAL JOURNAL OF ACADEMIC RESEARCH IN BUSINESS AND SOCIAL SCIENCES Vol. 8, No. 12, Dec, 2018, E-ISSN: 2222-6990 @ 2018 HRMARS

career skills, technical skills and soft skills. Therefore, it is vital for students to engage in internship because it has been proven by the past literature analysis of the study as well. It is better if internship programme coordinator is available to meet as needed for students and coordinate the activities of make students engaging in internship programme. Appraisals can be conducted for the students after engaging an internship programmes and special credits or marks can be allocated for the students who are successfully completed an internship programme.

Ultimate objective of this research is to identify whether there is a relationship between internship programmes and the employability. According to the research analysis correlation between the internship programmes and the graduate's employability is 0.739 , which indicates a strong positive linear relationship. And Sig. value which also called the P-Value is 0.000 , is less than 0.05, which concludes that there is a significant correlation between internship programs and graduates' employability.

\section{Correlations}

\begin{tabular}{|ll|r|r|}
\hline & & Internship & \multicolumn{1}{|c|}{ Employability } \\
\hline Internship & Pearson Correlation & 1 & $.739^{* *}$ \\
& Sig. (2-tailed) & 76 & .000 \\
& $\mathrm{~N}$ & $.739^{* *}$ & 76 \\
\hline Employability & Pearson Correlation & .000 & 1 \\
& Sig. (2-tailed) & 76 & \\
& $\mathrm{~N}$ & 76 \\
\hline
\end{tabular}

**. Correlation is significant at the 0.01 level (2-tailed).

The results of the study indicate that there is a strong positive relationship between the internship programmes and the employability. It was further identified that dimensions career skills, technical skills and soft skills identified to measure internship programs are also significant for the graduates' employability. It was shown that career skills, soft skills and technical skills which are correlations are respectively $0.625,0.710$, and 0.727 and are significantly related to the graduates' employability. This result indicates that graduates should be enabled to acquire those skills because those kind of skills are vital for them to acquire a better job and to be a better employee in the future. But with compared to other dimensions of the independent variable, the dimension 'incentive' shows a moderate level of relationship with graduates' employability with a correlation value of 0.372 , below than 0.5 .

\section{Limitations and Implications for future research}

The study concluded the positive strong relationship between the internship programmes and the graduates' employability. This study is mainly conducted for the BBA graduates at ABC University which is a private university. Even though questionnaire was also distributed for the BBA graduates in 2016. But there are many other universities in Sri Lanka. Therefore, future research can be more relate to the other private universities in Sri Lanka as well. 
Similarly, there are other several public universities in Sri Lanka. Thus future researchers can be focused public universities in Sri Lanka or covered the entire university system in Sri Lanka. And also comparative study also can be conducted between two universities or private and public universities.

Similarly, the study was measured internship programmes based on only four dimensions such as career skills, technical skills, soft skills and incentives. It might not limit for those dimensions. Therefore, future researchers can be related to identify more dimensions and measured.

Similarly, this study was mainly conducted as quantitative analysis. Therefore, future researchers can be conducted through qualitative analysis by using case study method because it might provide better understanding about the attitude of students who participated for internship programmes about the internship programmes and significance of participating for internship programmes for the better employability.

\section{Conclusion}

The main objective of this study is to examine the relationship between internship programmes and the graduates' employability. Findings of the study indicate that there is a relationship between the internship programmes and the employability accordance with correlation between the internship programmes and the employability. Therefore, the findings and results of the study are not much different from other similar kind of topics and studies which have been explained in past literature review of the study.

As per findings of the studies, researchers recommended the university to encourage students to go to the internship and getting organizations where they can gain the better experience on engaging in internships. It is better, if they can make participating for the internship as a compulsory requirement for the undergraduates who are following BBA degree programme because the study reveals that there is a relationship between internship programme and graduate's employability.

Also with the finalization of the data analysing process, it was clear that the research objectives have been achieved successfully. Those successful achievements are further explained under the topic discussion and findings of the research.

\section{References}

1. Ariyawansa, R. (2008). Employability of Graduates of Sri Lankan Universities. Sri Lankan Journal of Human Resource Management, 2(1), 91. doi:10.4038/sljhrm.v2i1.5107

2. Beard, F., \& Morton, L. (1998). Effects of Internship Predictors on Successful Field Experience. Journalism \& Mass Communication Educator, 53(4), 42-53. doi:10.1177/107769589805300404

3. Central Bank Annual report. (2016). Retrieved from http://www.cbsl.gov.Ik/pics_n_docs/10_pub/_docs/efr/annual_report/AR2016/English/8_C hapter_04.pdf

4. Clark, S. C. (2003). Enhancing the Educational Value of Business Internships. Journal of Management Education, 27(4), 472-484. doi:10.1177/1052562903251350 
INTERNATIONAL JOURNAL OF ACADEMIC RESEARCH IN BUSINESS AND SOCIAL SCIENCES Vol. 8, No. 12, Dec, 2018, E-ISSN: 2222-6990 C 2018 HRMARS

5. Devarajan, J. (2017). Graduate unemployment in Sri Lanka. Sunday Times. Retrieved from http://www.sundaytimes.lk/article/1022653/graduate-unemployment-in-sri-lanka

6. Dissanayake, E. (2011). Determinants of unemployment among Sri Lankan University Graduates. Colombo: Department of Manpower and Employment.

7. Hymon-Parker, S. (1998). Benefits and limitations of internships as viewed by educators and retailers/commentary. Journal of Family and Consumer Sciences (90), 76-81.

8. Mounce, P. H., Mauldin, D. S., \& Braun, R. L. (2004). The Importance of Relevant Practical Experience among Accounting Faculty: An Empirical Analysis of Students Perceptions. Issues in Accounting Education, 19(4), 399-411. doi:10.2308/iace.2004.19.4.399

9. Samarasinghe, M., (2003). Career Guidance Training for Over 10,000 Unemployed Graduates, Sri Lanka News by the Department of Information, Monday 17th February 2003.

10. Sekaran, U. (2006). Research methods for business: A skill-building approach. Chichester, West Sussex: Wiley.

11. Smith, C. D., Ferns, S., \& Russell, L. (2014). Assessing the impact of work-integrated learning (WIL) on student work readiness. Project information (website). Retrieved April 04, 2014, from http://www.olt.gov.au/project-assessing-impact-workintegrated-learning-wil-studentwork-readiness-2011

12. Thilakerathne, P. M., \& Madurapperuma, M. W. (2014). An examination of Accounting Internship on Subsequent Academic Performance. International Journal of Economics, Finance and Management Sciences, 2(1), 8. doi:10.11648/j.ijefm.20140201.12

13. Warinda, T. (2013). Accounting Students' Evaluation of Internship Experiences From A Skills Perspective. International Journal of Asian Social Science, 2013, 3(3):783-799

14. Weible, R. (2009). Are Universities Reaping the Available Benefits Internship Programs Offer? Journal of Education for Business, 85(2), 59-63. doi:10.1080/08832320903252397

15. Weligamage, S. \& Siengthai, S. (2003). Employer Needs and Graduate Skills: The Gap between Employer Expectations and Job Expectations of Sri Lankan University Graduates. Paper submitter for 9th International conference on Sri Lanka Studies, 28-30 November 2003, Matara, Sri Lanka 